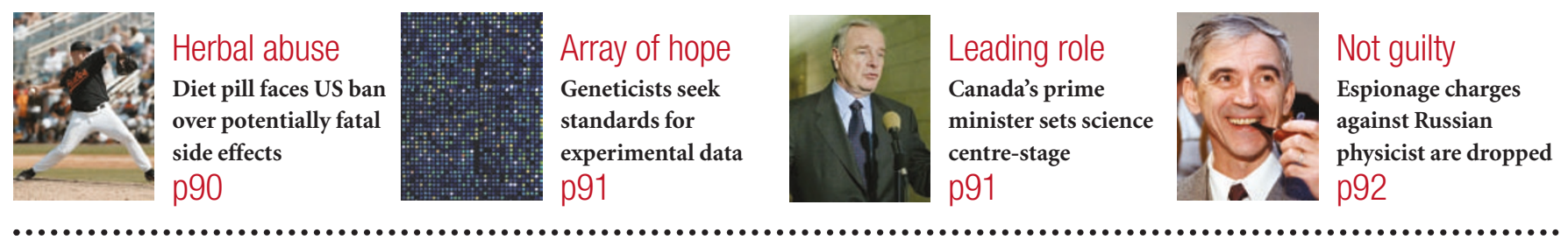

\title{
Rover barks before Beagle as Mars success lifts NASA's spirits
}

Tony Reichhardt, Washington

After landing on Mars on 3 January, NASA's Spirit rover is now flexing its mechanical limbs and surveying its surroundings before heading out to explore. Scientists and engineers at NASA's Jet Propulsion Laboratory (JPL) in Pasadena, California, who operate the desk-sized robot, are itching to investigate the various features seen in the pictures of the martian surface returned by the rover.

Based on those preliminary images, Steve Squyres, a planetary scientist at Cornell University in Ithaca, New York, and principal investigator for Spirit's scientific instruments, speculates that the rover has landed in a field of small craters at the centre of Gusev Crater, which is thought to be an ancient lake bed.

The terrain around the landing site is pocked with shallow depressions, which Squyres says may be secondary impact craters caused by material falling back to the surface after being thrown up by a larger impact. One such pit, which the Spirit team calls 'Sleepy Hollow', is likely to be the robot's first destination, as it looks to contain a rock outcrop that could offer insight into sedimentary history.

The rover had the good fortune to land in what Squyres called "the place where we absolutely wanted to be". The site is relatively free of boulders that would impede the robot. So mission controllers can bask in the

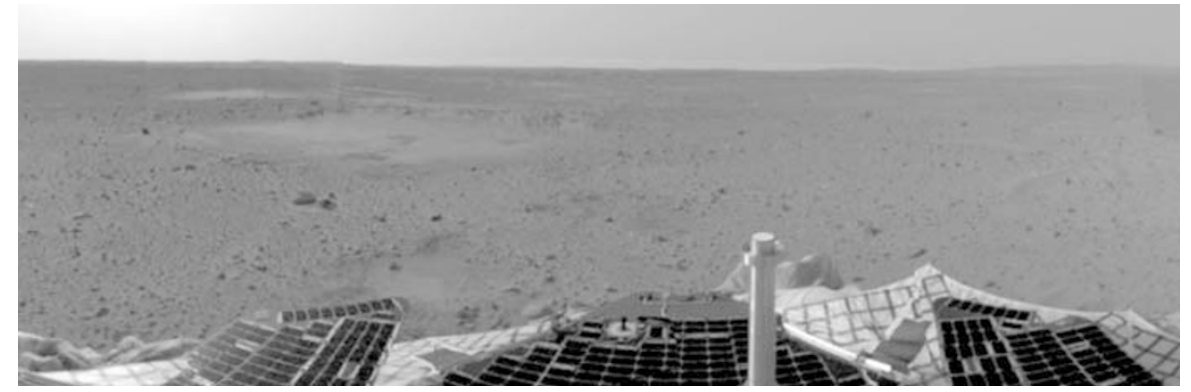

Land ahoy! Spirit's early view of Mars shows the small pit nicknamed 'Sleepy Hollow' centre left.

smooth, early operation of what was seen as a make-or-break mission for the JPL, which suffered embarrassing back-to-back failures in 1999 (see Nature 423, 477;2003).

Europe's first planetary orbiter, Mars Express, is also off to a promising start, with two successful orbit manoeuvres already under its belt, and another scheduled for this week to bring it closer to the planet's surface. Agustin Chicarro, the European Space Agency's project scientist for the mission, says that data from the onboard instruments should begin flowing in late January.

One of the spacecraft's key instruments, a ground-penetrating radar that aims to map water and ice to depths of several kilometres below the martian surface, will be deployed in late February. By April, says Chicarro, Mars
Express should settle into a schedule of routine scientific observations.

James Head, a planetary geologist at Brown University in Providence, Rhode Island, says that if the Mars Express radar works as advertised, it could shed light on what happened to the large reservoirs of water thought to have existed in the planet's distant past.

A second NASA rover, called Opportunity, is set to reach Mars on 24 January. That leaves the British-built Beagle 2 lander as the only troubled mission in the current invasion of Mars (see Nature 427, 5; 2004). Project managers hope that Mars Express can make contact with Beagle 2 sometime after 7 January. Highresolution cameras on NASA's orbiting Mars Global Surveyor have also been enlisted to take close-ups of the lost craft's landing site.

\section{Swift response greets return of SARS in China}

David Cyranoski, Tokyo

China is rushing to quell public fears after confirmation on 5 January of the first naturally acquired case of severe acute respiratory syndrome (SARS) since the disease was contained in July last year.

The patient, a television producer from the southern province of Guangdong, became ill on 16 December. He was isolated in hospital in the provincial capital of Guangzhou, and is now making a good recovery. The quarantine has been extended to 81 of his contacts, all of whom have remained healthy. "The system of identification and contact-tracing seems to be working," says Julie Hall, the Communicable Disease Surveillance and Response Coordinator for China at the World Health Organization (WHO).

The case was confirmed by tests carried out at two laboratories in Hong Kong and one in Beijing, which found a sharp rise in the patient's production of antibodies to the SARS virus. Researchers at the University of Hong Kong also say that the patient's virus is a close genetic match to samples taken from masked palm civets (Paguma larvata) and other animals in the markets in and around Guangzhou. On the basis of these results, provincial officials plan to kill some 10,000 civets currently held for sale for food.

But experts are questioning this strategy. "Raccoon dogs, badgers, ferrets, house cats and rodents can all carry the SARS virus," says Albert Osterhaus, a virologist at Erasmus University in Rotterdam, the Netherlands. "A more comprehensive approach is needed."

Meanwhile, concern about the resurgence of SARS has spread to the Philippines, where a domestic maid working in Hong Kong who returned home for a holiday has shown suspicious symptoms. Tests for SARS were being conducted as Nature went to press. 